\title{
Geochemical Characteristics of Carbonaceous Shales from the Surkha Lignite Mine, Saurashtra Basin, India: Implications for Gas Potential
}

\author{
Sanyasi Rao. Marrapu, Devleena Mani, Kalpana. M. S., Patil. D. J., Dayal. A. M. \\ CSIR- National Geophysical Research Institute, Hyderabad, India
}

\begin{abstract}
The carbonaceous shales collected from the Surkha lignite deposits of Saurashtra basin, Gujarat have been studied to decipher the source and quality of kerogen present in it. The pyrolysis and bulk carbon isotope ratio signatures have been determined using Rock Eval6 and EA-IRMS, respectively. Total Organic Carbon (TOC) content of thirty-five shale and lignite samples collected from the open cast lignite mine ranges between 0.4 and $52.4 \%$. The S1 and S2 values vary from 0.1 to $14.9 \mathrm{mg} \mathrm{HC/g}$ rock and 0.1 to $363.8 \mathrm{mg} \mathrm{HC/g}$ rock, respectively. Rock Eval thermal maturity indicator, Tmax values, varies between $404^{\circ} \mathrm{C}$ and $433^{\circ} \mathrm{C}$

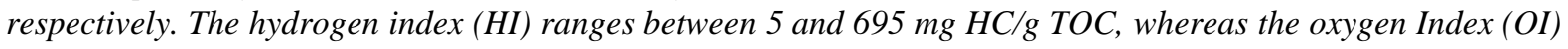
values ranges between 15 and $307 \mathrm{mg} \mathrm{CO}_{2} / g$ TOC. Organic matter (OM) is typified predominately by Type III kerogen, with partial contribution from Type IV kerogen. The Tmax and calculated Rock Eval VRo\% (<0.6) suggests immature stage for hydrocarbon generation. Rock Eval parameters, S1, S2, and TOC correlate well with each other and suggest the well preserved and unaltered nature of organic components. Bulk carbon isotope ratios $\left(\delta^{13} C\right)$ range between -22.7 to $-26.5 \%$ and indicate the contribution of OM from terrestrial land plants. Major element composition determined using XRF technique indicates it to be Fe-shale, with mineral matrix rich in smectite and illites. With shale gas and shale oil emerging as alternate source of energy in recent times, this study provides useful insights on the kerogen properties of the Surkha shales.
\end{abstract}

Keywords: Kerogen, Shales, Lignite, Pyrolysis, Carbon Isotopes, Major elements.

\section{INTRODUCTION}

Carbonaceous shales form important petroleum source rock globally. These are black to grey laminated shales, rich in organic content and pyrite. Generally, the shales are formed under reducing and anoxic conditions. OM present in the rocks under influence of pressure and temperature transforms to oil and gas in the subsurface. Oil shales, however, are not exposed sufficiently to necessary temperature and pressure for the transformation of $\mathrm{OM}$ and require external maturation conditions. Kerogen is the major source ( 80 to $90 \%$ ) for generation of hydrocarbons in these rocks. Formation of kerogen involves the conversion of lipids, proteins and carbohydrates of once living organisms into the $\mathrm{OM}$ of sedimentary rocks through various low temperature condensation and polymerization reactions (Hunt, 1996). When buried deeper at high temperatures, kerogen cracks to bitumen, which degrades to form oil and gas. Properties of kerogen such as its concentration, quality or type and its thermal maturity are important for the generation of oil and gas (Mishra et al., 2015).

Depending upon the OM quantity, a total organic carbon content (TOC in weight \%) of $<0.50$ is considered poor; 0.50 to 1.0 as fair; 1.0 to 2.0 as good and that $>2.0$ as excellent for generation of oil and gas in the source rocks (Hunt, 1996, Peter and Cassa, 1994). Based on the ratios of the elements carbon, hydrogen and oxygen the kerogen has been classified as into different Types namely I, II, III and IV (van Krevelen, 1961; Tissot and Welte, 1978). Type I and II generate oil and contain mainly aliphatic and few aromatic nuclei. The $\mathrm{H} / \mathrm{C}$ ratio is high. The $\mathrm{OM}$ is derived from lipids of algae or from organisms that are enriched in lipids by microbial activity (Tissot and Welte, 1978). Type-II kerogen contains more aromatic and naphthenic rings. The $\mathrm{H} / \mathrm{C}$ ratio and the hydrocarbon are lower. Type-II kerogen is generally found in marine organic matter deposited in reducing environments. Type-III kerogen generates largely gas, condensates and some waxes. It contains mostly condensed poly-aromatics and oxygenated functional groups, with minor aliphatic chains. The H/C ratio is low. The potential to generate oil is moderate for Type III kerogen. It may generate gas at greater depths. 
The $\mathrm{O} / \mathrm{C}$ ratio is comparatively higher. The $\mathrm{OM}$ is mostly derived from terrestrial higher plants (Tissot and Welte, 1984). Type IV kerogen generates little amount of methane and $\mathrm{CO}_{2}$. The van Krevelen diagram (van Krevelen, 1961) is used to evaluate the quality of kerogen based on the HI/OI values. The Hydrogen Index vs Tmax (Temperature at peak kerogen cracking) relationship obtained from the pyrolysis is used to infer the maturation state along with the kerogen type in the sedimentary OM (Tissot and Welte, 1978; Hunt, 1996).

The interbedded carbonaceous shales of the Surkha lignite mine, South-East of Bhavnagar, Gujarat, have been studied here for their OM quantity and quality. A suite of thirty- three shales and two lignite samples have been investigated using the open system pyrolysis (Rock Eval6 pyrolyzer) and bulk carbon isotope analyses (Elemental Analyzer-Isotope Ratio Mass Spectrometer) for understanding the source, kerogen type and thermal maturity of OM. As the mineral matrix influences the gas generation mechanism, the major element composition is also studied using XRF to understand the role of different clay minerals in assessing the thermal maturity of kerogen and its cracking into the gaseous hydrocarbons.

\section{GEOLOGICAL SETTING AND STRATIGRAPHY}

Saurashtra basin is located on the western margin of Indian sub-continent and is bounded by bounded by Kutch rift basin in the north, Cambay rift basin in the east and the Surat depression in the south (Biswas, 1982; Merh, 1995). The basin forms a horst block and is characterized by Lower Cretaceous sedimentation, followed by Deccan basalts and the Neogene and Quaternary aged rocks._The outcropping area is surrounded on three sides by the Arabian Sea and Gulf of Kutch and Cambay, whereas, the Gujarat alluvial plains mark its northeastern limit (Fig. 1). The alluvium overlies the Cambay rift basin sediments (Biswas, 1982; 1987). Marine to fluvio-marine tertiary sediments are deposited along the Western Continental Shelf. The Paleogene strata lie on the off shore area while the Neogene strata comprise the surface on shore exposures. These occur all along the south western and southern coast. The on-shore Neogene beds are range in age from the early Miocene to MioPliocene (Fedden 1884).

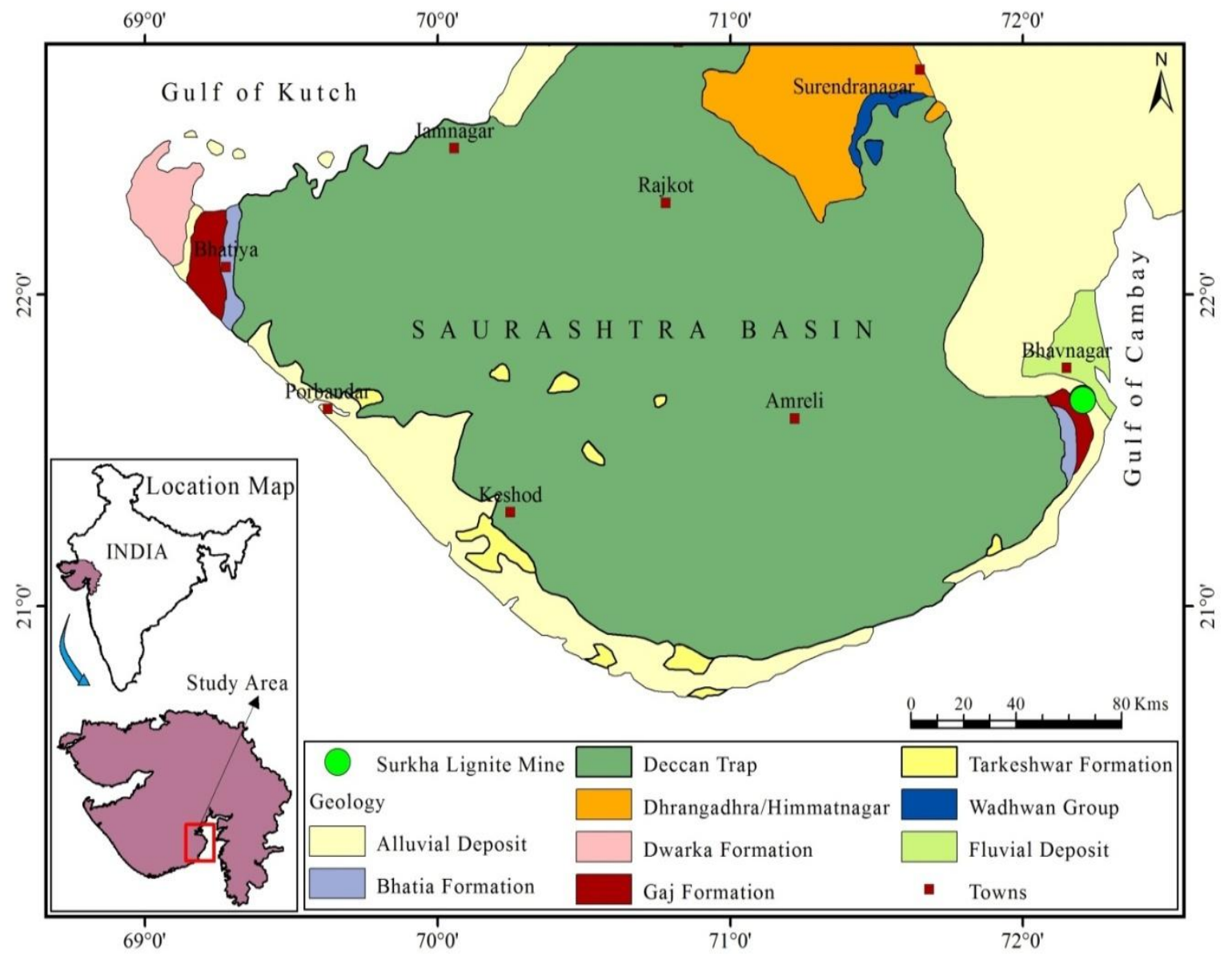

Fig1. Geological map of the Saurashtra basin showing the location of Surkha lignite mine (after Merh, 1995) 
Geochemical Characteristics of Carbonaceous Shales from the Surkha Lignite Mine, Saurashtra Basin, India: Implications for Gas Potential

The collected samples form part of the Gaj Formation belonging to Middle Miocene age. Gaj formation beds are divided into two members - the lower Ashapura Clay Member and upper Ranjitpur Limestone Member (Bhatt, 2000; Pandey et al., 2007; Kundal et al., 2014) (Table1). The Ashapura Clay Member contains variegated clay with gypsiferous bands and the Ranjitpur Limestone Member contains yellow and brown coloured fossiliferous limestone. In Gaj formation, the differential weathering of the constituent rocks has given rise to a gently undulating topography. The formation is highly fossiliferous, occupies a wide area of about $300 \mathrm{~km}^{2}$. The formation underlies the Dwarka Formation, which ranges from Middle Miocene to Lower Pleistocene, and divisible into three members. The Positra limestone member contains bioclastic and coralline limestone with few dolomicritic bands. The Shankhodar sand-clay Member contains sandy clay and sandstones and the Kalyapur Limestone Member contains recrystallized fossiliferous limestone and sandy limestone. Gaj formation is followed by the underlying Deccan Trap formation (Kundal et al., 2014). Detailed lithostratigraphy of the Surkha mine is given in Table 1.

Table1. Lithostratigraphy of Cenozoic- Quaternary deposits of Saurashtra basin (After Kundal et al., 2014)

\begin{tabular}{|c|c|c|c|}
\hline \multicolumn{2}{|c|}{ Stratigraphic Unit } & \multirow[t]{2}{*}{ Lithology } & \multirow[t]{2}{*}{ Age } \\
\hline Formation & Member & & \\
\hline \multicolumn{2}{|c|}{ Holocene deposits } & Beach and dune sands, tidal clays, alluvium & Holocene \\
\hline \multicolumn{4}{|c|}{ Unconformity } \\
\hline \multirow[t]{2}{*}{$\begin{array}{c}\text { Chaya } \\
\text { Formation }\end{array}$} & $\begin{array}{l}\text { Armada Reef Member } \\
\qquad(4 \mathrm{~m})\end{array}$ & $\begin{array}{l}\text { Coral algal reef, coral bafflestone and algal } \\
\text { rudstone with micro and mega fossils }\end{array}$ & \multirow{2}{*}{$\begin{array}{l}\text { Middle to } \\
\text { Late } \\
\text { Pleistocene }\end{array}$} \\
\hline & $\begin{array}{l}\text { Okha Shell Limestone } \\
\text { Member }(10 \mathrm{~m})\end{array}$ & $\begin{array}{l}\text { Cross bedded pack to rudstone, bioturbated shell } \\
\text { limestone with mega fossils. }\end{array}$ & \\
\hline \multicolumn{4}{|c|}{ Unconformity } \\
\hline \multirow[t]{2}{*}{$\begin{array}{l}\text { Miliolite } \\
\text { Formation }\end{array}$} & $\begin{array}{l}\text { Adatiana Member } \\
\qquad(5-50 \mathrm{~m})\end{array}$ & Pelletoid limestones (Calcarenites) & $\begin{array}{l}\text { Middle to } \\
\text { Late } \\
\text { Pleistocene }\end{array}$ \\
\hline & $\begin{array}{l}\text { DhobaliyaTalav Member } \\
\qquad(8-10 \mathrm{~m})\end{array}$ & $\begin{array}{l}\text { Alternating sequence of pelletoid limestone and } \\
\text { fine-grained limestone (micrites) }\end{array}$ & $\begin{array}{c}\text { Early Middle } \\
\text { Pleistocene }\end{array}$ \\
\hline \multicolumn{4}{|c|}{ Unconformity } \\
\hline \multirow[t]{3}{*}{$\begin{array}{c}\text { Dwarka } \\
\text { Formation }\end{array}$} & $\begin{array}{l}\text { Kalyapur Limestone } \\
\text { Member }(30 \mathrm{~m})\end{array}$ & $\begin{array}{l}\text { Recrystallized fossiliferous limestone and sandy } \\
\text { limestone }\end{array}$ & $\begin{array}{c}\text { Lower } \\
\text { Pliocene }\end{array}$ \\
\hline & $\begin{array}{l}\text { Shankhodar Sand-clay } \\
\text { Member }(60 \mathrm{~m})\end{array}$ & Sandy clays and sandstones & $\begin{array}{l}\text { Upper } \\
\text { Miocene }\end{array}$ \\
\hline & $\begin{array}{l}\text { Positra limestone } \\
\text { member }(25 \mathrm{~m})\end{array}$ & $\begin{array}{l}\text { Bioclastic and coralline limestone with few } \\
\text { dolomitic bands }\end{array}$ & $\begin{array}{l}\text { Middle } \\
\text { Miocene }\end{array}$ \\
\hline \multicolumn{4}{|c|}{ Unconformity } \\
\hline \multirow[t]{2}{*}{$\begin{array}{c}\text { Gaj } \\
\text { Formation }\end{array}$} & $\begin{array}{l}\text { Ranjitpur Limestone } \\
\text { Member }(5 \mathrm{~m})\end{array}$ & Yellow and brown fossiliferous limestone & \multirow{2}{*}{$\begin{array}{l}\text { Lower to } \\
\text { Middle } \\
\text { Miocene }\end{array}$} \\
\hline & $\begin{array}{l}\text { Ashapura Clay Member } \\
\qquad(90 \mathrm{~m})\end{array}$ & $\begin{array}{l}\text { Variegated clays with gypsiferous bands, } \\
\text { Carbonaceous shales, lignites }\end{array}$ & \\
\hline \multicolumn{4}{|c|}{ Nonconformity } \\
\hline & Deccan Trap & $\begin{array}{c}\text { Basalt and other derivatives covered at places by } \\
\text { laterite and bauxite }\end{array}$ & $\begin{array}{c}\text { Upper } \\
\text { Cretaceous } \\
\text { to Eocene }\end{array}$ \\
\hline
\end{tabular}

\section{Materials AND Methods}

\subsection{Field Sampling}

Thirty-five carbonaceous shale and lignite samples were collected from the open cast mine of Surkha of Saurashtra Basin, Gujarat, India (Fig. 1). A 500g of carbonaceous shale samples were collected from an elevation of $7-8 \mathrm{~m}$ by manual hammering of the shale horizons. The locations were marked using Global Positioning System (GPS). A field photograph of lignite and shale horizons in Surkha lignite mine is shown in Fig. 2. 


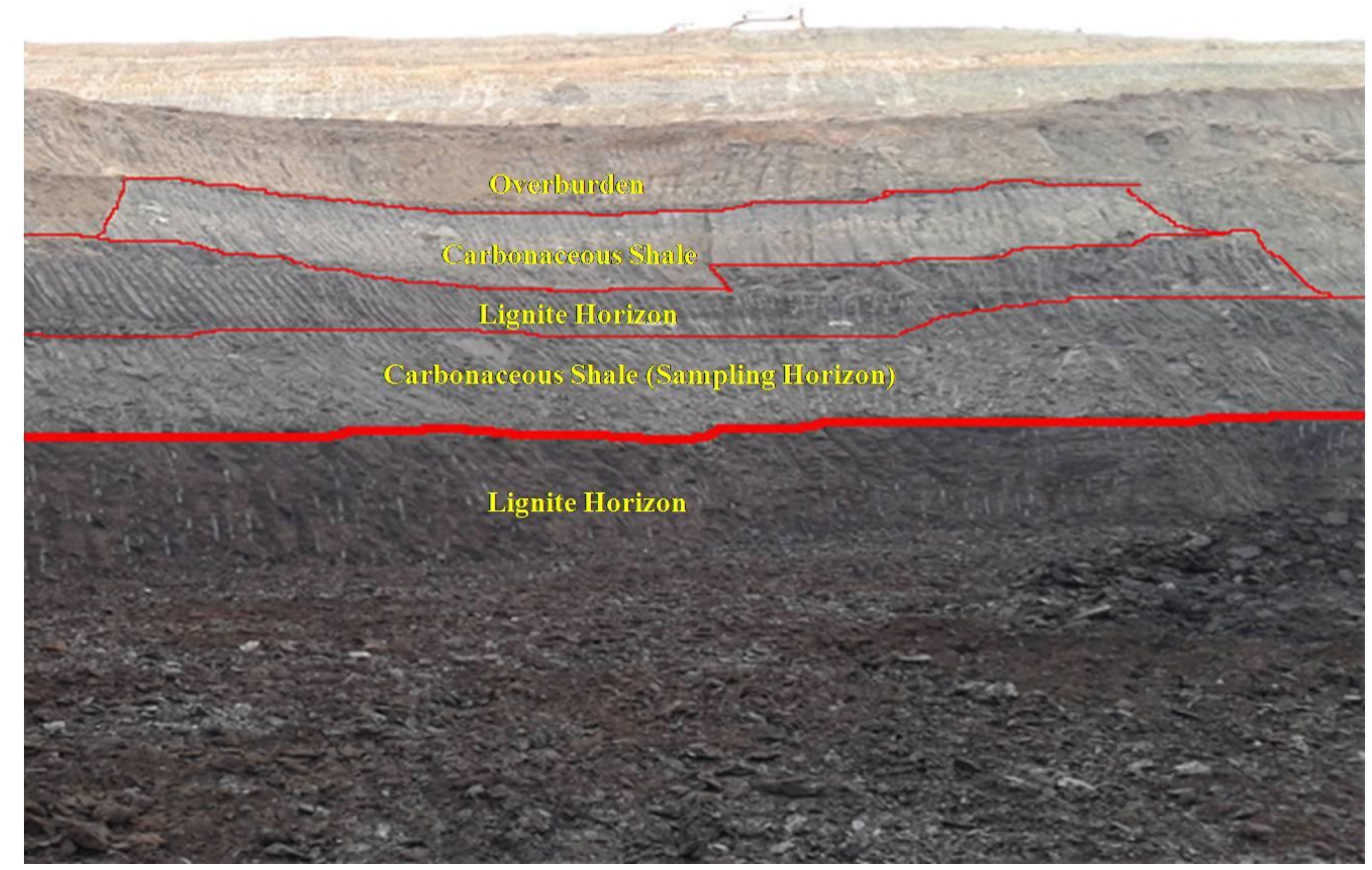

Fig2. Field photograph of the shale and lignite horizons exposed in the Surkha lignite mine

\subsection{Geochemical Analysis}

The carbonaceous shale and lignite samples were crushed into fine powder of about less than $63 \mu$ for the geochemical investigations. These samples were analyzed for TOC content and Rock Eval pyrolysis, bulk carbon isotope analysis $\left(\delta^{13} \mathrm{C}_{\mathrm{org}}\right)$ using EA-IRMS and major oxides compositions using X-ray Fluorescence spectrometry.

\subsubsection{Rock Eval Pyrolysis}

In Rock Eval pyrolysis, the OM is cracked thermally according to a programmed temperature pattern to know the quantity and quality of kerogen. A weighed sample of crushed source rock $(\sim 70-80 \mathrm{mg})$ is placed into a crucible, which is inserted into one of the holders of the automatic sampler fitted to the Rock Eval instrument. The analysis takes place in two steps. In the first step during the pyrolysis, the thermo-vaporized free hydrocarbons contained in the rock are released and detected by flame ionization detector (FID). With increasing temperature, the heavy hydrocarbons are liberated due to the cracking of OM (kerogen) in the rock, giving rise to the $\mathrm{S} 2$ peak and the simultaneously evolved $\mathrm{CO}$ and $\mathrm{CO}_{2}$ are detected by Infrared cell (S3 peak). S3 is an indication of the amount of oxygen contained in the kerogen and is used to calculate the oxygen index. Tmax is the temperature at the maximum of S2 peak during the pyrolysis process and is an indication of the maturation state of the $\mathrm{OM}$. In the second step during oxidation process, the $\mathrm{CO}$ and $\mathrm{CO}_{2}$ resulting from the combustion of rock, is measured by means of Infrared cell $\left(\mathrm{S} 4 \mathrm{CO}, \mathrm{S}_{4} \mathrm{CO}_{2}\right)$. The TOC content of the rock is determined by adding up of the pyrolyzable organic carbon and that of oxidation under air (residual organic carbon). The mineral carbon content is also measured as the sum of pyrolyzable and oxidative inorganic carbon content (Mani et al., 2014; 2015).

\subsubsection{EA-IRMS}

Bulk carbon isotope analysis $\left(\delta^{13} \mathrm{C}_{\text {org }}\right)$ of the shales was performed on a Thermo Finnigan FlashElemental Analyzer (TC/EA) attached to Delta ${ }^{\text {plus }} \mathrm{XP}$ isotope ratio mass spectrometer (IRMS). Sample weight of about 300-500 $\mu \mathrm{g}$. filled in the tin capsules was placed into the auto sampler. These samples were purged with a continuous flow of helium and then dropped into a vertical quartz tube maintained at $900^{\circ} \mathrm{C}$ (combustion reactor packed with Copper Oxide). Flash combustion of sample took place in the helium stream enriched with oxygen. The isotopic composition of $\mathrm{CO}_{2}$ was measured using IRMS. The Flash EA-IRMS was calibrated using international standards, NBS-22 and graphite, and the precision was found to be within $\pm 0.3 \%$ of the reported value (Mani et al., 2015). 
Geochemical Characteristics of Carbonaceous Shales from the Surkha Lignite Mine, Saurashtra Basin, India: Implications for Gas Potential

\subsubsection{X-ray fluorescence spectrometer analysis $(X R F)$}

The major elemental concentrations were determined in Philips Magi-X PRO Model PW 2440 X-ray fluorescence spectrometer attached to automatic sample changer PW 2540 and software SUPER Q 3.0 (Philips, Eindhoven, The Netherlands). The samples were ignited at $660^{\circ} \mathrm{C}$ for 40 minutes in silica crucibles for loss on ignition. The powdered samples were used to prepare pressed pellets of $40 \mathrm{~mm}$ diameter using collapsible aluminum cups the analysis. The cups were filled with boric acid and 1 to 2 grams of the finely powdered carbonaceous shale samples were evenly sprayed and hydraulically pressed to form a pellet. Matrix matching certified reference materials GSR-4 for sandstone and GSR5 for shale were used to calibrate the instrument (Mani et al., 2016).

\section{RESUlT AND DISCUSSION}

The Rock-Eval pyrolysis results and the bulk carbon isotope compositions are given in the Table 2 . The lignite samples (S-01, S-31) show a high value for thermo-vaporized free hydrocarbons $(\mathrm{S} 1=8.94$ and $14.89 \mathrm{mgHC} / \mathrm{g}$ rock) those from the cracking of $\mathrm{OM}$ (S2=197.23 and $363 \mathrm{mgHC} / \mathrm{g}$ rock). The thermal maturity indicator or the Tmax values are lower, $417^{\circ} \mathrm{C}$ and $413^{\circ} \mathrm{C}$ respectively for the two lignite samples. $\mathrm{CO}_{2}$ from organic source (S3) are 8.52 and $7.98\left(\mathrm{mgCO}_{2} / \mathrm{g}\right.$ Rock). TOC values are 48.15 and 52.38 (wt. \%) (Table 2). HI values, which is the ratio of S3 and TOC are 410 and $695 \mathrm{mg}$ $\mathrm{HC} / \mathrm{g}$ TOC). OI values, which is the ratio of $\mathrm{S} 3$ and TOC are 18 and 15 (S3/TOC, $\mathrm{mgCO}_{2} / \mathrm{g}$ TOC) respectively.

The carbonaceous shales have lower S1 values, ranging between 0 and $0.89 \mathrm{mgHC} / \mathrm{g}$ rock, (Table 2). The $\mathrm{S} 2$ values range between 0.1 and $41.06 \mathrm{mgHC} / \mathrm{g}$ Rock (Table 2). Tmax values range between 404 and $433^{\circ} \mathrm{C}$, indicating a thermally immature $\mathrm{OM}$ for the oil and gas generation (Table 2). TOC values lie between 0.4 and $24.34 \%$ (Table 2). S3 values range between 0.46 and $10.01 \mathrm{mgCO}_{2} / \mathrm{g}$ rock. HI values range between 29 and 212 (S2/TOC, $\mathrm{mgHC} / \mathrm{g}$ TOC), and indicates the kerogen to be Type III and Type II/III (Peters and Cassa, 1994; Table 2). OI values range between 17 and $307 \mathrm{mgCO}_{2} / \mathrm{g}$ TOC. A representative pyrogram containing the pyrolysis and oxidation curves for the studied sample is shown in Fig. 3. The bulk carbon isotopic values $\left(\delta^{13} \mathrm{Corg}\right)$ range between -22.7 and $-26.6 \%$ for the selected samples.

Table2. Rock Eval pyrolysis parameters data of Surkha carbonaceous shales from Saurashtra Basin

\begin{tabular}{|l|l|l|l|l|l|l|l|l|l|}
\hline Sample & S1 & S2 & Tmax & S3 & TOC\% & HI & OI & MINC \% & RE VR $_{\mathbf{O}} \%$ \\
\hline S-01 (lignite) & 8.94 & 197.23 & 417 & 8.52 & 48.15 & 410 & 18 & 1.12 & 0.35 \\
\hline S-02 & 0.22 & 31.26 & 426 & 3.83 & 18.28 & 171 & 21 & 0.4 & 0.51 \\
\hline S-03 & 0.25 & 8.33 & 428 & 1.26 & 3.92 & 212 & 32 & 0.14 & 0.54 \\
\hline S-04 & 0.89 & 40.32 & 423 & 10.01 & 24.34 & 166 & 41 & 0.65 & 0.45 \\
\hline S-05 & 0.48 & 41.06 & 427 & 7.06 & 19.85 & 207 & 36 & 0.49 & 0.53 \\
\hline S-06 & 0 & 0.33 & 420 & 0.46 & 0.94 & 35 & 49 & 0.13 & 0.4 \\
\hline S-07 & 0.02 & 1.08 & 429 & 1.67 & 1.99 & 54 & 84 & 0.22 & 0.56 \\
\hline S-08 & 0.01 & 0.45 & 420 & 0.74 & 0.89 & 51 & 83 & 0.11 & 0.4 \\
\hline S-09 & 0 & 0.42 & 419 & 0.77 & 1.01 & 42 & 76 & 0.15 & 0.38 \\
\hline S-10 & 0.01 & 0.36 & 422 & 0.81 & 0.78 & 46 & 104 & 0.12 & 0.44 \\
\hline S-11 & 0 & 0.23 & 415 & 0.48 & 0.55 & 42 & 87 & 0.07 & 0.31 \\
\hline S-12 & 0 & 0.02 & 433 & 0.33 & 0.4 & 5 & 82 & 0.68 & 0.63 \\
\hline S-13 & 0 & 0.13 & 430 & 1.31 & 0.91 & 14 & 144 & 6.58 & 0.58 \\
\hline S-14 & 0 & 0.1 & 432 & 1.72 & 0.56 & 18 & 307 & 0.58 & 0.62 \\
\hline S-15 & 0 & 0.3 & 423 & 1.17 & 1.85 & 16 & 63 & 0.19 & 0.45 \\
\hline S-16 & 0 & 0.52 & 417 & 4.44 & 3.11 & 17 & 143 & 0.46 & 0.35 \\
\hline S-17 & 0 & 0.17 & 422 & 2.41 & 1.14 & 15 & 211 & 0.18 & 0.44 \\
\hline S-18 & 0.01 & 0.52 & 421 & 1.26 & 1.95 & 27 & 65 & 0.16 & 0.42 \\
\hline S-19 & 0.08 & 3.67 & 430 & 2.28 & 5.02 & 73 & 45 & 0.43 & 0.58 \\
\hline S-20 & 0 & 0.82 & 425 & 1.53 & 2.16 & 38 & 71 & 0.24 & 0.49 \\
\hline S-21 & 0.2 & 2.52 & 421 & 2.37 & 4.22 & 60 & 56 & 0.33 & 0.42 \\
\hline S-22 & 0.27 & 10.91 & 416 & 4.13 & 9.34 & 117 & 44 & 0.35 & 0.33 \\
\hline S-23 & 0.73 & 16.05 & 426 & 2.21 & 10.1 & 159 & 22 & 0.28 & 0.51 \\
\hline S-24 & 0.38 & 11.59 & 416 & 2.85 & 10.4 & 111 & 27 & 0.32 & 0.33 \\
\hline S-25 & 0.23 & 9.14 & 428 & 1.27 & 5.83 & 157 & 22 & 0.22 & 0.54 \\
\hline S-26 & 0.25 & 10.12 & 426 & 1.43 & 6.06 & 167 & 24 & 0.16 & 0.51 \\
\hline & & & & & & & & & \\
\hline
\end{tabular}


Sanyasi Rao. Marrapu et al.

\begin{tabular}{|l|l|l|l|l|l|l|l|l|l|}
\hline S-27 & 0.22 & 8.38 & 424 & 1.54 & 6.14 & 136 & 25 & 0.16 & 0.47 \\
\hline S-28 & 0.03 & 1.26 & 423 & 1.42 & 2.84 & 44 & 50 & 0.21 & 0.45 \\
\hline S-29 & 0.29 & 11.29 & 430 & 2.12 & 5.55 & 203 & 38 & 0.21 & 0.58 \\
\hline S-30 & 0.24 & 9.7 & 428 & 0.88 & 5.13 & 189 & 17 & 0.16 & 0.54 \\
\hline S-31 (lignite) & 14.89 & 363.79 & 413 & 7.98 & 52.38 & 695 & 15 & 0.74 & 0.27 \\
\hline S-32 & 0.11 & 4.17 & 427 & 1.24 & 2.91 & 143 & 43 & 0.11 & 0.53 \\
\hline S-33 & 0 & 0.4 & 422 & 0.54 & 0.67 & 60 & 81 & 0.24 & 0.44 \\
\hline S-34 & 0.04 & 0.36 & 404 & 0.82 & 1.26 & 29 & 65 & 0.12 & 0.11 \\
\hline S-35 & 0.28 & 13.52 & 428 & 1.79 & 5.55 & 244 & 32 & 0.17 & 0.55 \\
\hline
\end{tabular}

[TOC (wt. \%); S1, S2 (mgHC/g Rock); S3 (mgCO 2 g Rock); Tmax $\left({ }^{\mathrm{O}} \mathrm{C}\right)$;

$\mathrm{HI}$ (S2/TOC, mgHC/gTOC); OI (S3/TOC, $\mathrm{mgCO}_{2} / \mathrm{g}$ TOC); \&

Rock Eval Vitrinite Reflectance $\left(\mathrm{RE} \mathrm{VR}_{\mathbf{0}}\right) \%=0.018 \times$ Tmax-7.16]

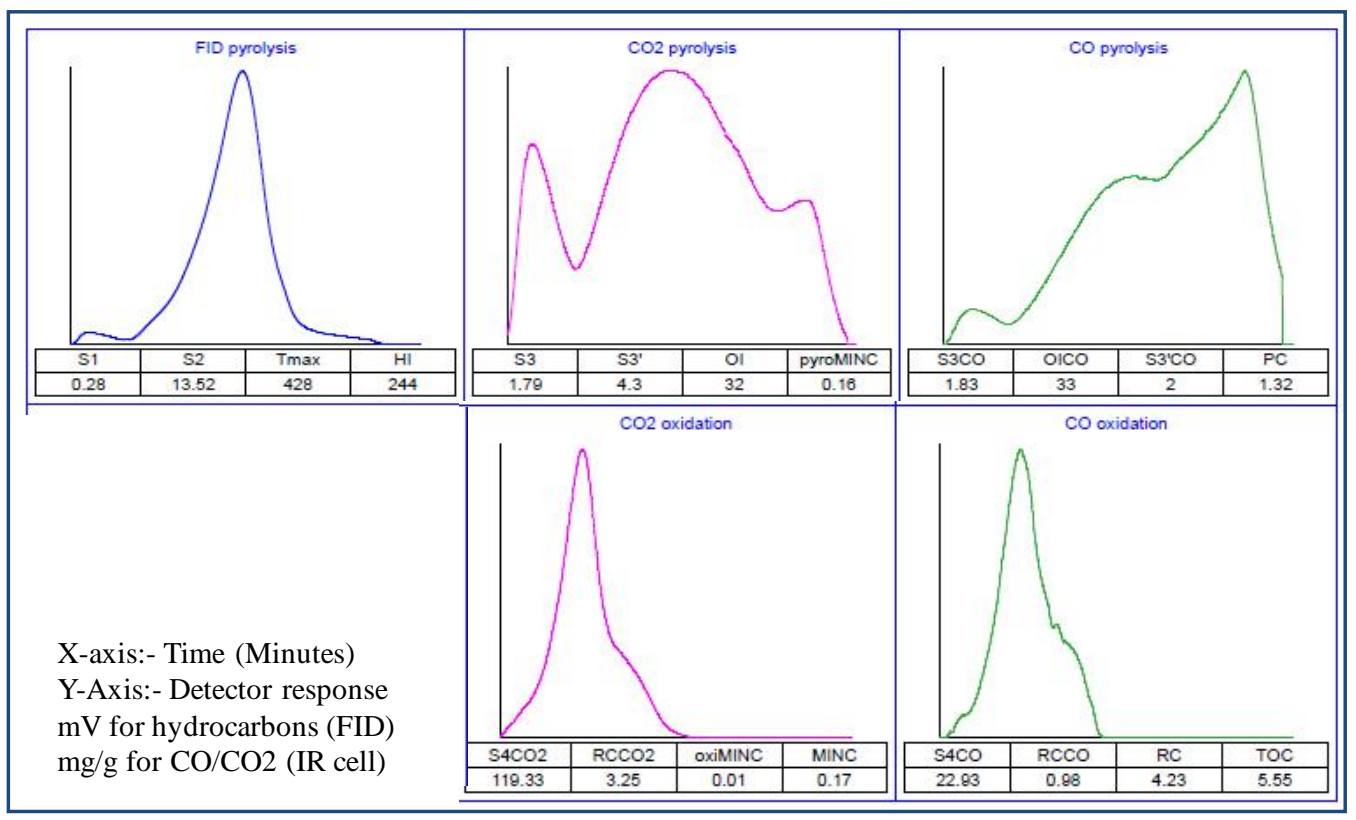

Fig3. Representative Rock Eval pyrolysis and oxidation curves of the carbonaceous shale sample (S-35) from Surkha lignite mine.

The OM in Surkha shales is characterized by a high TOC, which suggests it to have potential for the oil and gas generation (Peters and Cassa, 1994). There exists a very good to excellent correlation between $S 1$ and $S 2$ values $\left(r^{2}=0.9\right)$. These parameters also vary linearly with the TOC $\left(r^{2}=0.8\right)$ content of the $\mathrm{OM}$, indicating the well preserved and unaltered nature of $\mathrm{OM}$ in the shales (Tissot and Welte, 1978). A modified van Krevelen diagram (van Krevelen, 1961; Tissot and Welte, 1984) has been used to determine the type and maturation state of kerogen based on HI/OI values. The HI versus OI plot of the shales associated with lignite mine from Surkha indicates that the OM is characterized by Type III and Type IV kerogen (Fig. 4). A large majority of samples have HI $>50$ and nearly $50 \%$ of such samples have HI between 150-200, which suggests that OM is capable of generating oil and gas. When OM and coals have high hydrogen content relative to carbon, they can form oil (Hunt, 1996). The HI value below $50 \mathrm{mg} \mathrm{HC/g}$ TOC suggests a Type IV kerogen which produces no oil and gas. Type III kerogen, ranging between 50 and $200 \mathrm{mg} \mathrm{HC/g}$ TOC, produces gas. Type II/III kerogen, ranging between 200 and $300 \mathrm{mg} \mathrm{HC/g}$ TOC, produces mixed oil and gas. Type II ranging between 300 and $600 \mathrm{mg} \mathrm{HC} / \mathrm{g}$ TOC produces oil. Type I ranging above $600 \mathrm{mg} \mathrm{HC} / \mathrm{g}$ TOC produces oil. The Tmax values below $435{ }^{\circ} \mathrm{C}$ show an immature stage for hydrocarbon generation; the values 435 to $465^{\circ} \mathrm{C}$ suggest a mature stage for oil generation; whereas above $465^{\circ} \mathrm{C}$ show a post mature stage suitable for gas generation (Mishra et al., 2014). The HI versus Tmax correlations of the shales associated with lignite mine from Surkha shows thermally immature OM, characterized by Type III and Type IV kerogen (Fig. 5). Rock Eval vitrinite reflectance, calculated using the Tmax data of Surkha samples $\left(0.018 \times\right.$ Tmax $^{-}$7.16; Jarvie and Lundell, 1991), ranges from 0.3 to 0.6 Ro \% (Table 2). It suggests that samples are not exposed to sufficient heat for the oil or gas generation. These shales, where buried at deeper horizons in the basin, may achieve an appropriate thermal maturity for the generation of liquid and gaseous hydrocarbons. 
Geochemical Characteristics of Carbonaceous Shales from the Surkha Lignite Mine, Saurashtra Basin, India: Implications for Gas Potential

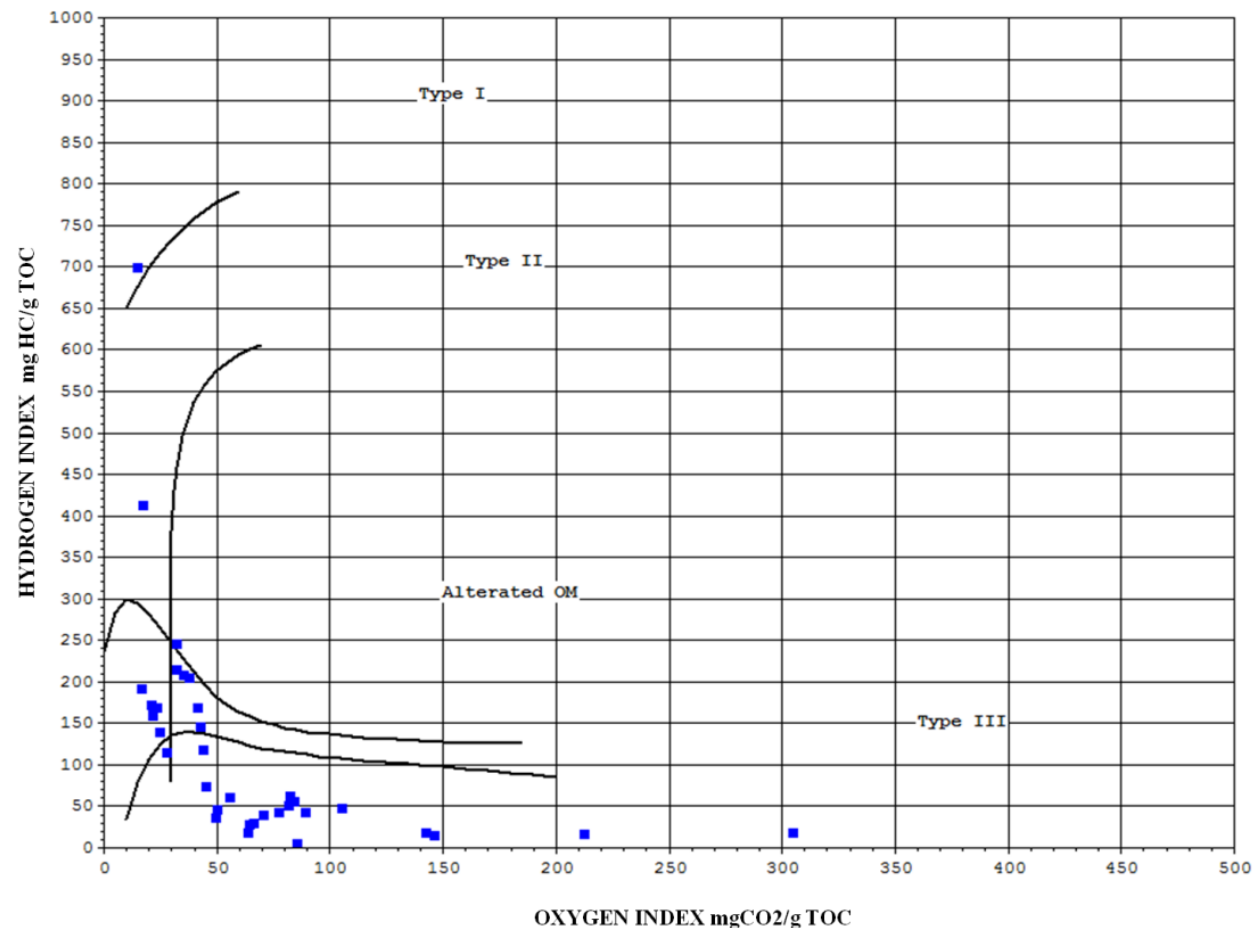

Fig4. HI versus Tmax correlation of the OM in the Surkha carbonaceous shales, Saurashtra Basin

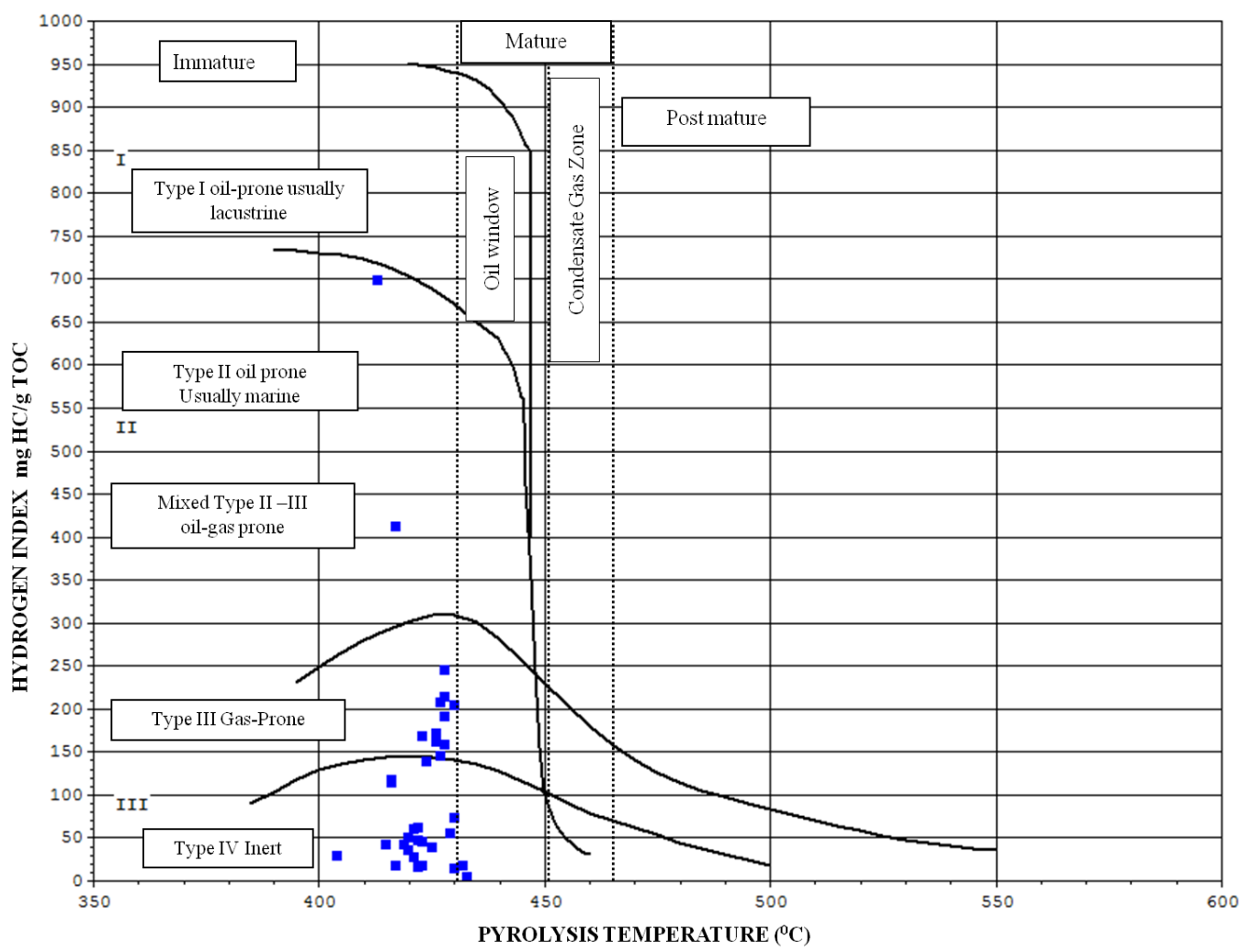

Fig5. Correlation between the HI and OI values in OM from the Surkha carbonaceous shales, Saurashtra Basin

The bulk stable carbon isotope composition indicates the contribution from terrestrial higher plants (Table 3). Differences in the carbon sources of the marine and continental (terrestrial and freshwater) plants are depicted in their_ $\delta^{13} \mathrm{C}$ isotopic compositions(Mani et al., 2015). In general, $\delta^{13} \mathrm{C}$ for marine plants ranges from $-8 \%$ to $-17 \%$, whereas for land plants it ranges from $-22 \%$ o to $-29 \%$ (Hoefs, 2009). The bulk OM in Surkha shales is derived from the polyaromatic woody tissues of higher land plants and is capable of generating gas. The variation of carbon isotope ratios with TOC is given in Fig. 6 (Wang et al., 2015). The samples with high TOC have depleted $\delta^{13} \mathrm{C}$ values, which also suggest the input of terrigenous material during the deposition of these sediments. 
Sanyasi Rao. Marrapu et al.

Table3. Bulk organic carbon isotope ratios for the carbonaceous shales from the Surkha lignite mine, Saurashtra Basin

\begin{tabular}{|c|c|c|c|c|c|c|c|c|c|}
\hline Sample & $\mathrm{S}-01^{\odot}$ & S-03 & S-05 & S-07 & S-09 & S-11 & S-15 & S-17 & S-19 \\
\hline$\delta^{13} C_{\text {org }}(\%)$ & -26.412 & -26.501 & -25.901 & -24.591 & -25.218 & -25.113 & -25.314 & -25.308 & -25.642 \\
\hline Sample & S-21 & S-23 & S-25 & S-27 & S-29 & $\mathrm{S}-31^{\odot}$ & S-33 & & S-35 \\
\hline$\delta^{13} C_{\text {org }}(\%)$ & -25.823 & -25.676 & -25.606 & -25.816 & -26.352 & -26.584 & -22.7 & & -25.815 \\
\hline
\end{tabular}

${ }^{\circ} \mathrm{S}-01$ \& S-31 samples are lignites

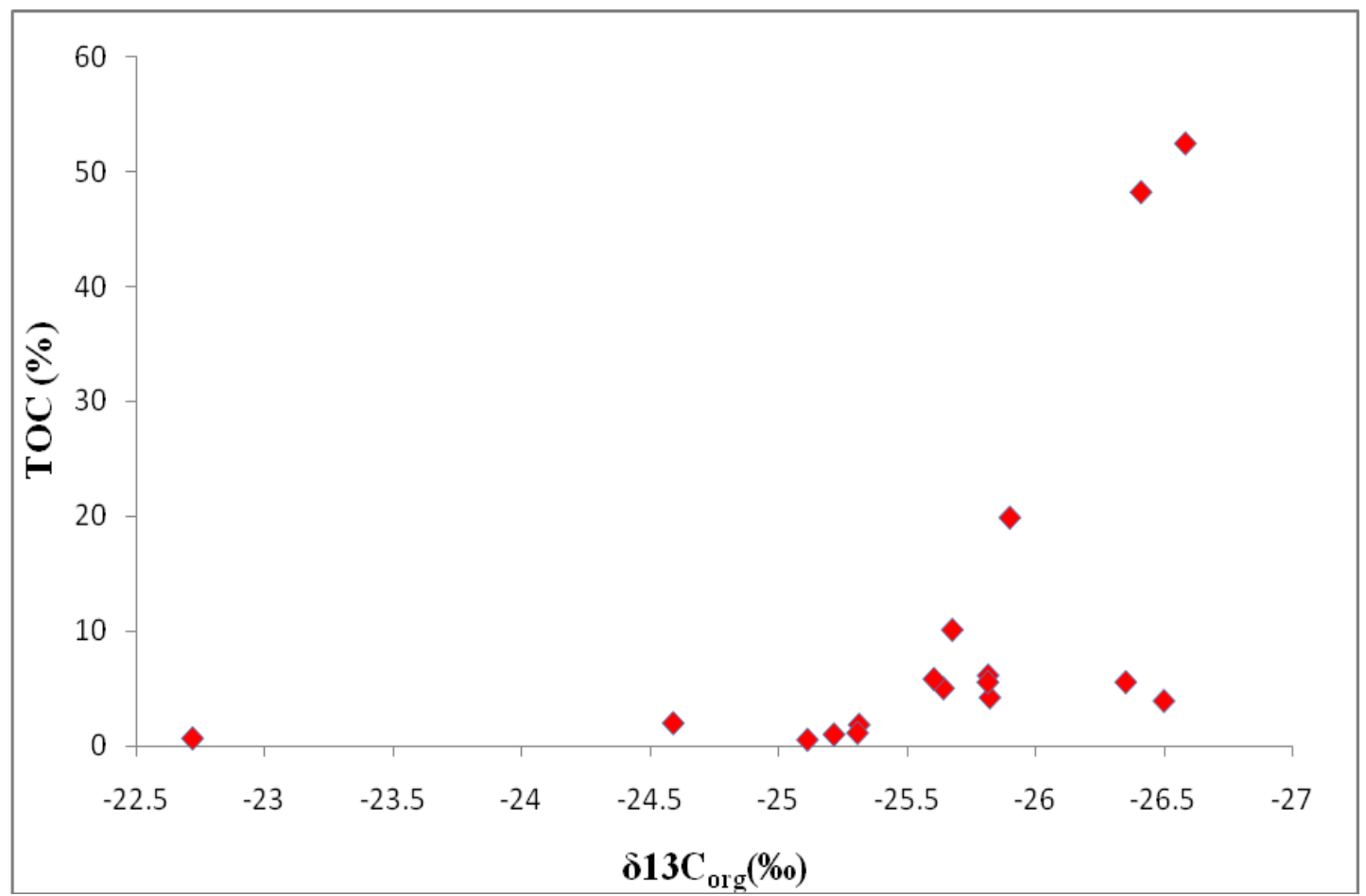

Fig6. Variation of bulk carbon isotope values with TOC content in the carbonaceous shales from the Surkha lignite mine (after Wang et al., 2015)

The major elemental oxides data of selected carbonaceous shales from Surkha lignite mine were determined using XRF (Table 4). The $\mathrm{SiO}_{2}$ content of the shales varies from 34.2 to $40.5 \%$. The $\mathrm{Al}_{2} \mathrm{O}_{3}$ content ranges from 10.1 to $21.5 \%$. $\mathrm{Fe}_{2} \mathrm{O}_{3}$ content varies between 4.15 to $12.02 \%$ and $\mathrm{MnO}$ varies from 0.02 to $0.08 \%$. The major element content of carbonaceous shales is nearly similar to the published values of average shale (PAAS ans NASC) (clarke,1924). However SiO2 values are compratively lower (Figs. 7; 8). Elevated concentrations of $\mathrm{MgO}, \mathrm{CaO}$ and $\mathrm{Na}_{2} \mathrm{O}$ are observed in the studied samples (Table 4 ; Fig. 7).

Table 4: Major oxides data of Surkha carbonaceous shales compared to PAAS and NASC.

\begin{tabular}{|c|c|c|c|c|c|c|c|}
\hline Sample No & $\mathbf{S - 0 1}$ & $\mathbf{S - 0 4}$ & $\mathbf{S - 1 9}$ & $\mathbf{S - 2 3}$ & $\mathbf{S - 2 9}$ & PAAS & NASC \\
\hline $\mathbf{S i O}_{\mathbf{2}}(\%)$ & 34.22 & 39.61 & 38.99 & 39.65 & 40.52 & 62.8 & 64.8 \\
\hline $\mathbf{A l}_{\mathbf{2}} \mathbf{O}_{\mathbf{3}}(\%)$ & 10.14 & 21.54 & 18.55 & 16.57 & 19.09 & 18.9 & 16.9 \\
\hline $\mathbf{F e}_{\mathbf{2}} \mathbf{O}_{\mathbf{3}}(\boldsymbol{\%})$ & 4.15 & 5.55 & 11.55 & 12.02 & 10.87 & 7.61 & 6.33 \\
\hline $\mathbf{M n O}(\%)$ & 0.03 & 0.02 & 0.08 & 0.04 & 0.05 & 0.11 & 0.06 \\
\hline $\mathbf{M g O}(\%)$ & 26.37 & 22.87 & 22.54 & 23.14 & 23.14 & 2.2 & 2.85 \\
\hline $\mathbf{C a O}(\%)$ & 16.6 & 4.49 & 2.02 & 2.03 & 1.21 & 1.3 & 3.56 \\
\hline $\mathbf{N a}_{\mathbf{2}} \mathbf{O}(\%)$ & 5.74 & 1.85 & 0.69 & 0.86 & 0.74 & 1.2 & 1.15 \\
\hline $\mathbf{K}_{\mathbf{2}} \mathbf{O}(\%)$ & 0.05 & 0.05 & 0.68 & 0.27 & 0.32 & 3.7 & 3.99 \\
\hline $\mathbf{T i O}_{\mathbf{2}}(\%)$ & 3.11 & 3.04 & 3.17 & 4.07 & 3.89 & 1.0 & 0.78 \\
\hline $\mathbf{P}_{\mathbf{2}} \mathbf{O}_{\mathbf{5}}(\%)$ & 0.07 & 0.04 & 0.53 & 0.1 & 0.1 & 0.16 & 0.11 \\
\hline
\end{tabular}


Geochemical Characteristics of Carbonaceous Shales from the Surkha Lignite Mine, Saurashtra Basin, India: Implications for Gas Potential

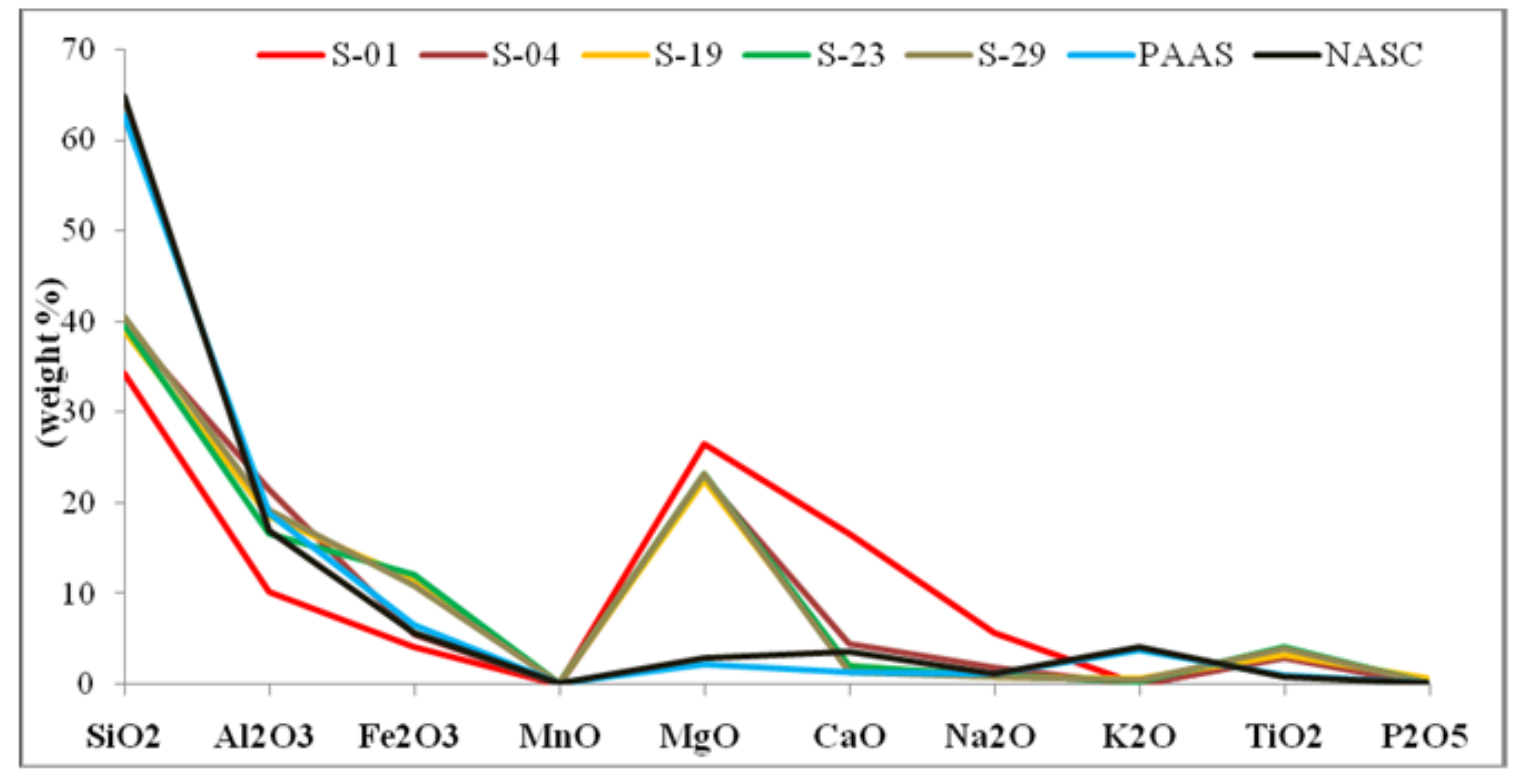

Fig7. The Major elemental chemistry of Surkha carbonaceous shales versus PAAS and NASC (after Mani et al., 2016).

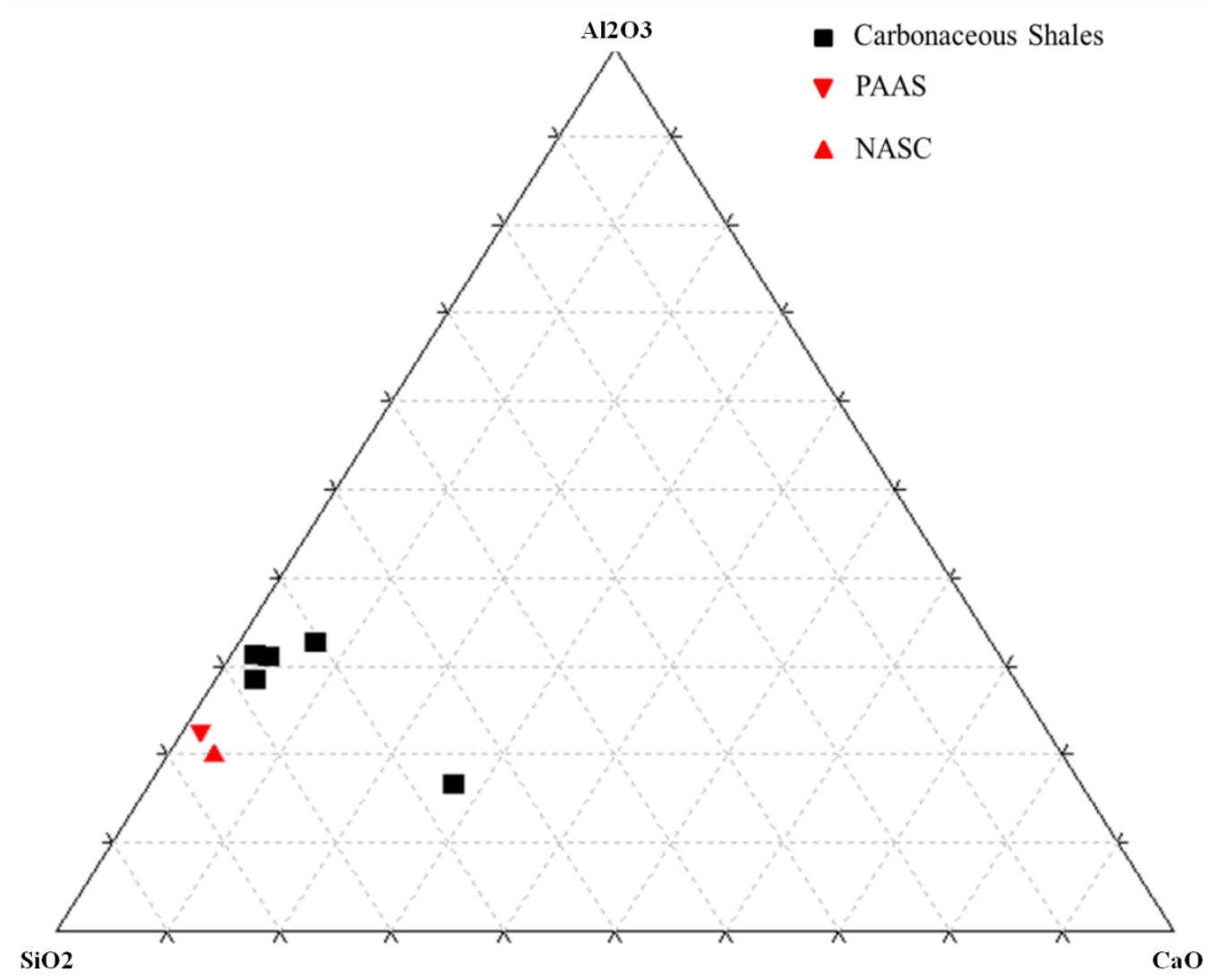

Fig8. Q-F-C Ternary diagram of carbonaceous shales from Surkha lignite mine, Saurashtra Basin.

These sediments owe their provenance from Deccan Basalts which cover a large part of Saurashta basin (Fig. 1). The studied shales have been characterized using classification of Heron, 1988 $\left[\log \left(\mathrm{Fe}_{2} \mathrm{O}_{3} / \mathrm{K}_{2} \mathrm{O}\right)\right.$ vs $\left.\log \left(\mathrm{SiO}_{2} / \mathrm{Al}_{2} \mathrm{O}_{3}\right)\right]$. The major oxides show a distribution in the Fe-shale lithofacies (Fig. 9). In the A-CN-K diagram, intensely weathered samples are plotted with high CIA (80-100), where incipiently weathered samples plot near the feldspar zone CIA (50-70) (Mani et al., 2016). The XRF data of the studied samples show the CIA value vary between $75-90$, which indicates a moderate to high degree of weathering and alteration. In A-CN-K diagram (Fig. 10), sample trend suggests the Smectite -Illite source composition. The relationship of $\mathrm{Na}_{2} \mathrm{O}$ with $\mathrm{Al}_{2} \mathrm{O}_{3}$ $\left(r^{2}=0.671\right.$, Fig. 11) suggests that these elements are associated with a constant detrital source. 


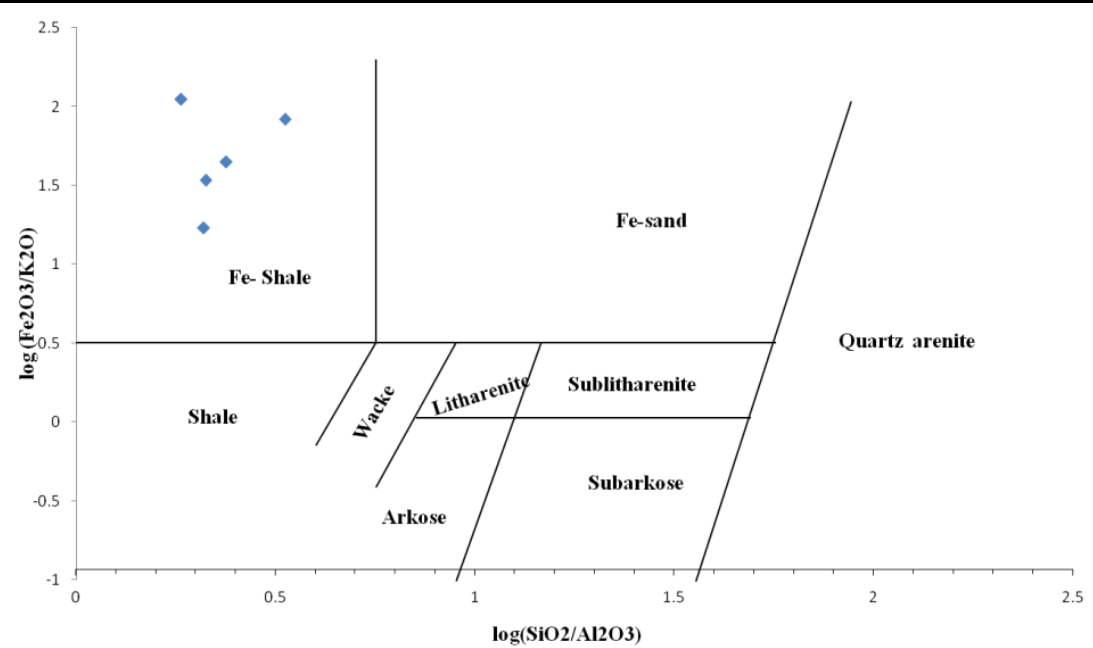

Fig9. Classification of terrigenous sandstones and shales using major oxide data $\left[\log \left(\mathrm{Fe}_{2} \mathrm{O}_{3} / \mathrm{K}_{2} \mathrm{O}\right)\right.$ virus $\log \left(\mathrm{SiO}_{2} / \mathrm{Al}_{2} \mathrm{O}_{3}\right)$ ] of Surkha lignite mine, Saurashtra Basin(after Herron, 1988)

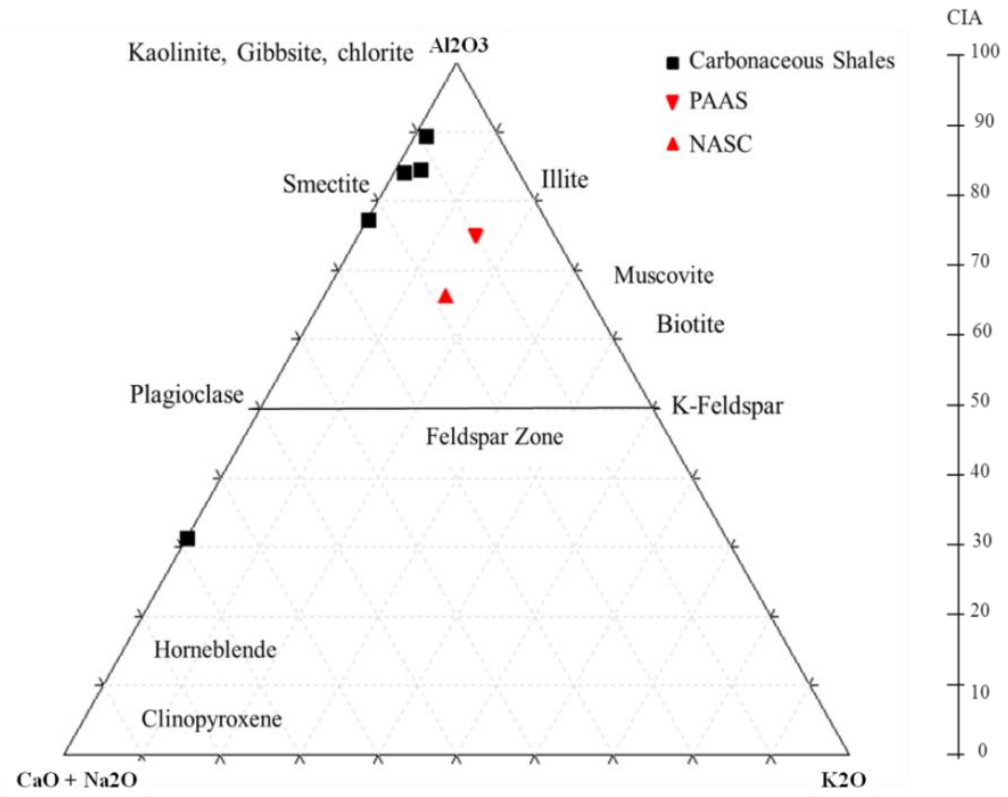

Fig10. $\mathrm{Al}_{2} \mathrm{O}_{3}-\mathrm{CaO}+\mathrm{Na}_{2} \mathrm{O}$ and $\mathrm{K}_{2} \mathrm{O}(\mathrm{A}-\mathrm{CN}-\mathrm{K})$ Ternary diagram for the CIA values of carbonaceous shales from Surkha lignite mine, Saurashtra Basin

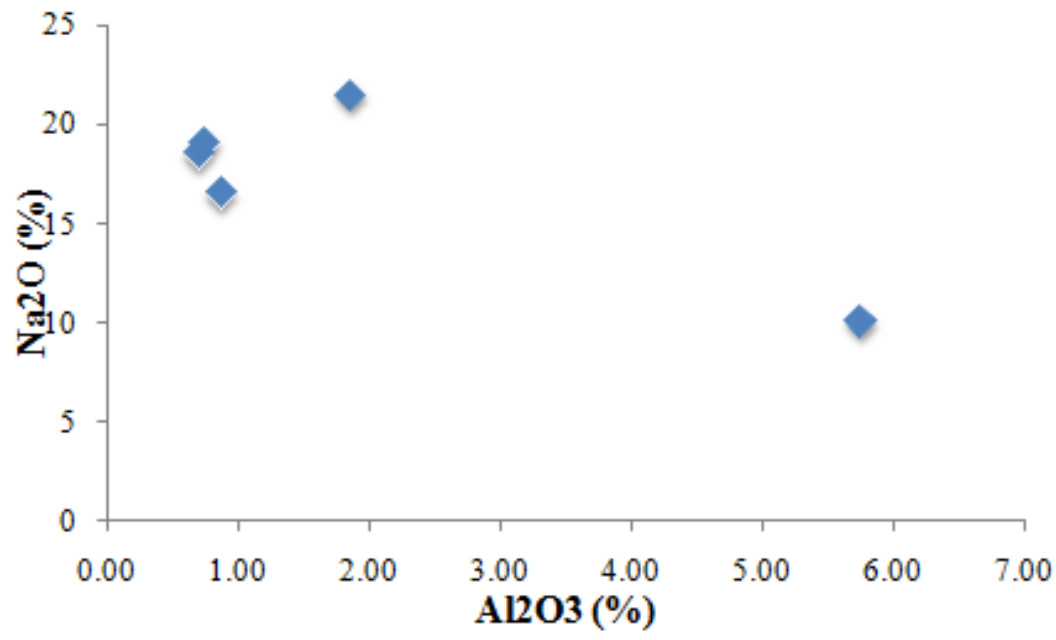

Fig11. Correlation of $\mathrm{Al}_{2} \mathrm{O}_{3}$ with $\mathrm{Na}_{2} \mathrm{O}$ concentrations in carbonaceous shales from Surkha lignite mine, Saurashtra Basin

The clay mineralogy of the studied samples is dominated by the Smectite and Illite composition (Fig. 10). Due to the small particle size, high surface area and ability to complex with polar organic substances, smectites achieve intimate mixing with organic substances and produce highly dispersed 
clay-organic system (Johns, 1979). It has been observed that subsurface diagentic conditions, particularly the temperatures, for generation of hydrocarbons coincides with the clay mineral alterations such as changes from montmorillonite to mixed-layer montmorillonite/illite to illite and changes in ordering of illite/smectite (I/S) from random to ordered I/S. Percentage of I/S decrease sharlply where the Tmax values are in oil generation zones. The Rock Eval Tmax data of the studied samples suggests it to be in immature to early oil window. This is also supported by the XRF data where the samples tend to show more of the smectite composition and hence a radom or lowered I/S (Fig. 10).

Mineralogy plays important role in controlling the kerogen pyrolysis products. Particularly, the clay mineral smectite tends to get expanded and act as a catalyst during the thermal decomposition of OM in the subsurface (Johns, 1979). It has been observed that during Rock Eval pyrolysis of smaples having lower TOC, the mineral matrix with quartz, calcite etc. may retain some of the S2 or catalyze the thermal decomposition of the kerogen, thereby altering the S2 signatures (Espitalie et al., 1980, 1984; Dembicki, 1983). The shales studied here have low TOC with abundance of quartz and clay minerals, which could possibly account for the reduced amount of pyrolysed hydrocarbons during the open system pyrolysis. The variability for both the Tmax and HI is wide, which also suggets some effect of surficial weathering and oxidation on the outcrop samples.

Thus, as indiacted by the S1, S2 and TOC content, the shales are rich in OM but have low thermal maturity for the generation of hydrocarbons. This is also suported by the mineral data with a low I and $\mathrm{S}$ ratio. The shales buried at a greater depth in the basin may have appropriate thermal maturity and can be investigated for detailed studies. The high sillica and alumina content of the shale samples offers the brittleness property, which makes it suitable for hydraulic fracturing considerations as well (Fig. 8).

\section{Conclusion}

The Rock Eval pyrolysis results of the interbedded carbonaceous shales from the Gaj formation of Surkha lignite mine of Saurashtra Basin, Gujarat indicate high TOC content, with dominantly gas prone Type III \& IV kerogen in thermally immature stage. The kerogen is likely to be in mature stage in the deep seated shale horizons. Bulk carbon isotope ratios suggest that the gas prone kerogen is derived largely from the higher terrestrial land plants. However; with high hydrogen content, the kerogen of the Surkha shales is capable of generating oil and gas. With smectites as major clay mineral, its contribution on thermal maturity and cracking of kerogen also holds importance in pyrolytic yields. The study provides encouraging results for detailed characterization of shales at greater depth in the basin in terms of their lithology, porosity, permeability etc. towards its assessment for shale gas and shale oil prospects.

\section{ACKNOWLEDGEMENT}

We are thankful to Gujarat Mineral Development Corporation (GMDC) for allowing the sample collection in the mine. Oil Industry Development Board (OIDB), New Delhi is acknowledged for providing financial supporting in setting up of the geochemical laboratory facility at NGRI. We are grateful to the Director, NGRI for the permission to publish this work. This work forms part of SHORE Project of NGRI under the 12th Five Year Scientific Program of CSIR.

\section{REFERENCES}

[1] Bhatt, N., (2000). Lithostratigraphy of Neogene-Quaternary deposits of Dwarka-Okha area, Gujarat. Jour. Geol. Soc. Amer, 84: 883-904.

[2] Biswas, S.K., (1982). Rift basins in western margin of India and their hydrocarbon prospects with special reference to Kutch Basin. AAPG Bull, 66: 1497-1513.

[3] Biswas, S.K., (1987b). Regional tectonic frame work, structure and evolution of the western marginal basins of India Tectonophysics, 135(4): 307-327.

[4] Clarke, F.W., (1924). Data of Geochemistry. Bulletin U.S. Geological Survey, 700.

[5] Dembicki, H. Jr., Horsfield, B., and Ho, T. T. Y., (1983). Sourcerock evaluation by pyrolysis-gas chromatography. Am.Assoc. Pet. Geol. Bull, 67: 1094-1103.

[6] Espitalie, J., Madec M. and Tissot., (1980). Role of mineralmatrix in kerogen pyrolysis: Influence on petroleum generationand migration. Bull. Am. Assoc. Pet. Geol, 64: 59-66. 
[7] Espitalie, J., Senga Makadi, K., Trichet, J., (1984). Role of the mineral matrix during kerogen pyrolysis. Org. Geochem, 6: 365-382.

[8] Fedden, F., (1884). Geology of Kathiawar peninsula in Gujarat.Mem. Geol. Surv. India, 21(2): 78-125.

[9] Herron, M. M., (1988). Geochemical classification of terrigenous sands and shales from core or log data. J. Sediment. Petrol, 58: 820-829.

[10] Hunt, M.J., (1996). Petroleum Geochemistry and Geology, Third Edition. W. H. Freeman and Company, England, 622.

[11] Jarvie, D.M., Lundell, L.L., (1991). Hydrocarbon Generation Modeling of Naturally and Artificially Matured Barnett Shale, Ft.Worth Basin, Texas, Southwest Regional Geochemistry Meeting, Sept, 8-9: 1991, The Woodlands, Texas.

[12] Johns, William D., (1979). Clay mineral catalysis and petroleum generation, Annu. Rev. Earth Planet. Sci, 7: 183-198.

[13] Kundal, P., Kundal Milind, P., Mude, S. N., (2014). Neogene-Quaternary Calcareous Algae from Saurashtra Basin, Western India: Implications on Paleoenvironments and Hydrocarbon Exploration, Jour. Geol. Soc. India, 83: 183-190.

[14] Kundal, P., Mude, S. N., (2004). Record of Coralline Algae from Lower Miocene Gaj Formation of Porbandar, Southwest Coast of Saurashtra: Paleoenvironment and Paleobathymetric implications. Gondwana Geol. Magz, 19(2): 159-164.

[15] Kundal, P., Mude, S. N., (2009a). Nongeniculate coralline algae from the Early Miocene to Late Holocene sequence of the Porbandar area, Saurashtra, Gujarat, India. Jour. Palaeont. Soc. India, 54(1): 73-80.

[16] Kundal, P., Mude, S. N., (2009b). Geniculate coralline algae from the Neogene-Quaternary sediments in and around Porbandar area, Saurashtra, Gujarat, India. Jour. Palaeont. Soc. India, 74(2): 276-274.

[17] Mani, D., Patil, D. J., Dayal, A. M., Prasad, B. N., (2015). Thermal maturity, source rock potential and kinetics of hydrocarbon generation in Permian shales from the Damodar Valley basin, Eastern India. Marine and Petroleum Geology, 66 (4): 1056-1072.

[18] Mani, D., Kavitha, S., Hafiz, M., Hakhoob, N., Bhat, G. M., (2014). Gas potential of Proterozoic and Phanerozoic shales from the NW Himalaya, India: Inferences from pyrolysis. International Journal of Coal Geology, 128-129: 81-95.

[19] Mani, D., Ratnam, B., Kalpana, M.S., Patil, D.J., Dayal, A.M., (2016). Elemental and organic geochemistry of Gondwana sediments from the Krishna-Godavari Basin, India. Chemie der Erde, 76 (1): 117-131.

[20] Merh, S. S., (1995). Geology of Gujarat. Geological Society of India, Bangalore, 102-124.

[21] Mishra, Snigdharani., Mani, D., Kavitha, S., Patil, D. J., Kalpana, M. S., Vyas, D. U., and Dayal, A. M., (2015). "Pyrolysis results of shales from the south Cambay basin, India: Implications for gas generation potential", Journal of the geological society of India, 85: 647-656.

[22] Mishra, Snigdharani., Mani, D., Kavitha, S., Kalpana, M. S., Patil, D. J., Vyas, D. U., and Dayal, A. M., (2014). "Organic matter characteristics and gas generation potential of the tertiary shales from NW Kutch, India”, Journal of Petroleum science and Engineering, 124: 114-121.

[23] Nesbitt, H. W., Young, G. M., (1982). Early Proterozoic climates and plate motions inferred from major element chemistry of lutites. Nature, 299: 715-717.

[24] Pandey, D. K., Bahadur, T., Mathur, U. B., (2007). Stratigraphic distribution and depositional environment of the Chaya formation along the Northwestern coast of Saurashtra peninsula, Western India, Jour. Geol. Soc. India, 69(6): 1215-1230.

[25] Peters, K.E., and Cassa, M.R., (1994). Applied source rock geochemistry, in Magoon, L.B., and Dow, W.G., eds., The petroleum system-From source to trap: Tulsa, Okla., American Association of Petroleum Geologists Memoir, 60: 93-117.

[26] Shu Jiang., (2012). Clay minerals from the perspective of oil and gas exploration. Energy \& Geoscience institute, University of Utah, Salt lake city, USA.

[27] Tissot, B.P., Welte, D.H., (1978). Petroleum Formation and occurrence. A new approach for oil gas exploration Springer Verlag, Berlin, Heidelberg, 538.

[28] Tissot, B.P., Welte, D.H., (1984). Petroleum Formation and Occurrence, $2^{\text {nd }}$ ed. Springer Verlag, Heidelberg. 
Geochemical Characteristics of Carbonaceous Shales from the Surkha Lignite Mine, Saurashtra Basin, India: Implications for Gas Potential

[29] Van Krevelen, D.W., (1961). Graphical-statistical method for the study of structure and reaction processes of coal. Fuel, 29: 269-284.

[30] Wang, S., Zou, C., Dong, D., Wang, Y., Li, X., Huang, Jinliang., Guan, Q., (2015). Multiple controls on the paleoenvironment of the Early Cambrian marine black shales in the Sichuan Basin, SW China: Geochemical and organic carbon isotopic evidence. Marine and Petroleum Geology, 66: 660-672.

\section{AUTHORS' BIOGRAPHY}

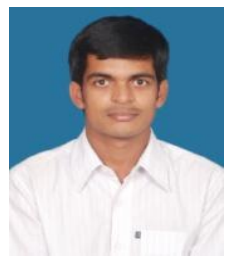

Mr. Marrapu. Sanyasi Rao, has completed M.Sc in Geology from Andhra University, Visakhapatnam in 2013. His research focuses on shale gas exploration and he is perusing $\mathrm{PhD}$. on the topic 'Shale gas potential of Saurashtra basin Gujarat, India' at Petroleum Geochemistry Group at CSIR-National Geophysical Research Institute, Hyderabad.

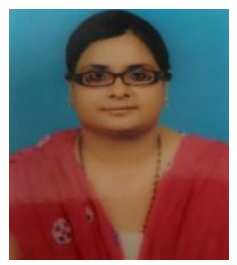

Dr. Devleena Mani, is an organic geochemist at CSIR-NGRI, Hyderabad. She studies isotopic and biomarker characteristics of sedimentary organic matter, paleo and depositional environment, thermal history of source rocks and kinetics of kerogen cracking. She also works on geochemical evaluation of hydrocarbon and shale gas systems and development \& application of analytical methods for geological materials using stable isotope and organic mass spectrometry. Dr. Mani has authored 35 peer reviewed papers in leading journals and contributed to the more than 25 projects for various oil and gas industries in India.

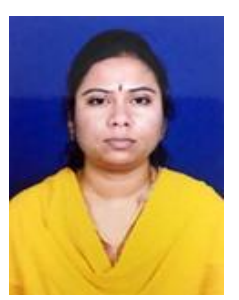

Dr. M.S. Kalpana, received her M.Sc. (Analytical Chemistry) degree from University College for Women, Osmania University and Ph.D. in Applied Geochemistry from Osmania University. Dr. Kalpana is currently working as a Senior Scientist in Gas Hydrates and other conventional and unconventional resources group at National Geophysical Research Institute. Her primary research fields are geochemical prospecting of hydrocarbons, development and application of geochemical and isotopic tracers for shale gas and paleo environmental studies with particular focus on biomarkers. She was associated with surface geochemical prospecting studies for hydrocarbon exploration in frontier on land sedimentary basins of India. She has published 26 papers in national and international journals and presented 20 papers in national and international seminar/symposium/meetings.

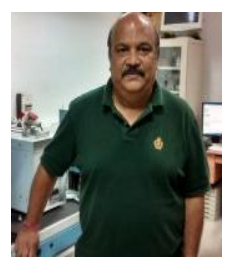

Dr. D.J.Patil, heads the Stable isotope and Petroleum Geochemistry group at CSIRNGRI, Hyderabad. He specializes in the fields of Stable isotope geochemistry and its application to environmental and hydrological studies, Conventional and unconventional Hydrocarbon exploration, Stable isotope Mass spectrometry. He has been Involved in establishing state of the art facilities for petroleum exploration by at NGRI which include: Gas Chromatography (GC), Continuous Flow- Isotope Ratio Mass Spectrometer (CF-IRMS) and Microbiology Labs. He has actively participated in petroleum exploration studies for Directorate General of Hydrocarbons (DGH), Gas Authority of India (GAIL), Oil and Natural Gas Corporation Limited (ONGC), Oil India Limited (OIL), Gujarat State Petroleum Corporation (GSPC), Jubilant Enpro Pvt. Ltd. etc for evaluation of hydrocarbon potential of different sedimentary basins in India. He has published 88 national and international papers.

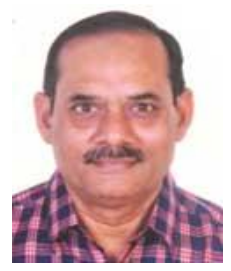

Dr. A.M. Dayal, is CSIR- Emeritus scientist at National Geophysical Research Institute (NGRI), Hyderabad and works on shale gas potentials in different basin of India. Born in 1952, he has an M.Sc and Ph.D. from Pune University in geology. He led the Petroleum Geochemistry Group for hydrocarbon research and was associated with projects of exploration companies like ONGC, Reliance India, Gas Authority India Limited, Prize petroleum, Gujarat State Petroleum Corporation and Jubilant Oil and gas. He has received DAAD fellowship from DST and INSA fellowship for Royal Society of London. He has more than 100 scientific papers in peer reviewed journals and has also presented several papers in national and international seminar. He has edited a book on shale gas potential by Elsevier. 